\title{
CALAMBA WATER DISTRICT SERVICE DELIVERY STANDARDS \\ IMPLEMENTATION AND CUSTOMER SATISFACTION: BASIS FOR \\ ENHANCEMENT PROGRAM
}

MONETTE C. ALZONA

monettealzona@yahoo.com

Laguna College of Business and Arts, Calamba City, Laguna, 4027, Philippines

\begin{abstract}
This study concluded that based on the data present, the Calamba Water District has effectively implemented the Citizen's Charter RA 9485 service delivery standards. However, there should still be room for enhancement of delivery standards for public service, and the researcher suggested this as a room for future researchers to ponder and expound on
\end{abstract}

Keywords: customer satisfaction; service; standards; implementation; enhancement; calamba water district

\section{Main text}

Service delivery standards are followed as is a practical way to manage performance in an era of fiscal restraint and help shape the expectations of clients have of government services. With service delivery standards, services can be improved and delivered at reduced cost by refocusing services on clients. It includes finding out what clients consider to be critical aspects of government services and service delivery, giving managers the flexibility to respond to client needs, developing proper incentives to promote innovation, and monitoring and analysing performance against realistic targets and standards. As an integral part of good management, service delivery standards promote partnership in quality client service; provide the means to measure service performance and costs reliably. It also provided meaningful information on the content, value and method of service delivery, and used performance and client satisfaction information to guide operational decisions to improve service standards and actual performance continually 


\section{Theoretical Framework}

The study was based on the concept of the Philippine Implementing Rules and Regulation (IRR) known as Citizen's Charter of RA 9485. In accordance to this, for transparency and smooth transactions in all government offices, all government offices must adhere to the following service standards: All government agencies including departments, bureaus, offices, instrumentalities, or government-owned and/or controlled corporations, or local government or district units shall set up their respective service standards to be known as the Citizen's Charter in the form of information billboards which should be posted at the main entrance of offices or at the most conspicuous place, and in the form of published materials written either in English, Filipino, or in the local dialect, that detail: the procedure to obtain a particular service, acceptance of applications and request that all officers or employees shall accept written applications, requests, and/or documents being submitted by clients to the office or agencies. However, the person/s responsible for each step are the officers or employee who should acknowledge with receipt of such application and/or request by writing or printing clearly thereon his/her name, the unit where he/she is connected with, and the time and date of receipt.

The maximum time to conclude the process of all applications and/or requests submitted should be acted upon by the assigned officer or employee during the period stated in the Citizen's Charter which shall not be longer than five working days in the case of simple transactions and ten (10) working days in the case of complex transactions from the date the request or application was received. Depending on the nature of the frontline services requested or the mandate of the office or agency under unusual circumstances, the maximum time prescribed above may be extended. For the extension due to nature of frontline services or the mandate of the office or agency concerned the period for the delivery of frontline services shall be indicated in the Citizen's Charter. The office or agency concerned shall notify the requesting party in writing of the reason for the extension and the final date of release for the extension and the final date of release of the frontline service/s requested; the document/s to be presented by the customer, if necessary.

The receiving officer or employee shall perform a preliminary assessment of the request so as to promote a more expeditious action on requests. The amount of fees, if necessary to be collected should be included in the assessment of the service being requested and the procedure for filing complaints. Also, the act also mandates to establish a public assistance/complaints desk in all their offices at least two information desk to accommodate concessionaires.

Under the said Law, each office or agency is tasked to perform in identifying its frontline services and whose charge. Reengineering of transactions that includes limiting the number of signatories to a maximum of five (5) and providing for the period within which applications or request are acted upon which shall not be longer than five (5) working days for simple transactions and ten (10) working days for complex transactions. Setting up of 
standards to be known as the Citizen's Charter, includes forming a task force to prepare the said charter, to present it on a billboard or other prominent announcement at the office handling the processes and services explained therein.

The study also used the RA 11032 or the Ease of Doing Business and Efficient Government Service Delivery Act, which aimed to streamline the current systems and procedures of government services.

\section{Conceptual Framework}

The aspect under the Independent Variable is the service delivery standards of Citizens Charter R.A.9485 of Calamba Water District (CWD) in terms of procedure to obtain a particular service; the person/s responsible for each step, maximum time to conclude the process; document/s to be presented by the customer; amount of fees; and procedure for filing complaint, while the process to relate the independent to the dependent variable referred to the level of stakeholders' satisfaction on ease of doing business on the aspect of customer service, quality of service delivery, easy transaction of documents and if all action and complaints are well taken.

\section{Research Paradigm}

\section{Independent Variable}

\begin{tabular}{|l} 
1. Level of service delivery standards \\
of citizen's charter R.A. 9485 of \\
Calamba Water District (CWD) \\
- The procedure to obtain a \\
particular service; \\
- The person/s responsible for \\
each step; \\
- The maximum time to \\
conclude the process; \\
The document/s to be \\
presented by the customer, if \\
necessary; \\
The amount of fees, if \\
necessary; \\
The procedure for filing \\
complaints
\end{tabular}

\section{Dependent Variable}

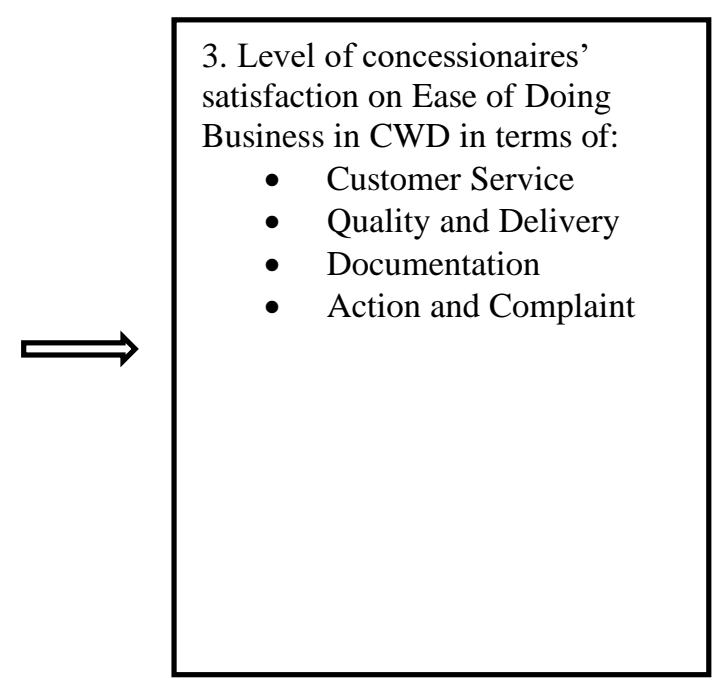

As illustrated in Figure 1, the aspects reflected under the Independent Variable is the service delivery standards of Citizens Charter R.A.9485of Calamba Water District 
(CWD) in terms of procedure to obtain a particular service; the person/s responsible for each step, maximum time to conclude the process; document/s to be presented by the customer; amount of fees; and procedure for filing complaint. An arrow pointed toward the Dependent Variable refers to the level of stakeholders' satisfaction on ease of doing business on the aspect of customer service, quality of service delivery, easy transaction of documents and if all action and complaints are well taken.

\section{Scope and Delimitations}

This study was focused on the assessment in the service delivery standards of Citizen's Charter R.A. 9485 as implemented by Calamba Water District (CWD) and was limited only on the procedure to obtain a particular service; person/s responsible for each step; the maximum time to conclude the process; document/s to be presented by the customer, if necessary; amount of fees, if necessary; and the procedure for filing complaints. It also disclosed the stakeholders' level of satisfaction on the ease of doing business with CWD in terms of customer service, quality and delivery, documentation requirements, and the taking of action on complaint. The commercial service areas or department was chosen as the locale of the study for they are directly involved in the effectiveness and appropriate implementation of Citizens Charter R.A. 9485 service standards.

The respondents of the study was the 41 office personnel of CWD directly involved in the implementation of CWD Citizen's Charter service standards and the 386 residents of Calamba City with water connections and concessionaires.

Because of the ongoing health pandemic caused by COVID-19, the data was gathered through survey questionnaires in accordance to Inter-agency Task Force (IATF) health safety protocols.

\section{Review of Related Literature}

Perante-Calina and Brillantes (2018) states the relevance of bureaucratic inefficiency to the ineffective delivery of services as well as corruption. Osborne and Gaebler (2019) cited the United Kingdom as the origin for strong impetus for bureaucratic reform for efficient and effective delivery of public services, which came from Prime Minister Margaret Thatcher in the late 80's. Calina and Brillantes (2018) also provides the help of the Filipino citizens to stop Anti-Red Tape Act as well as the effective implementation of the Citizen's Charter.

However, most of the abovementioned studies focused on red tape and the relevance of corruption in bureaucratic inefficiency. These also cited implementation as a crucial way for service delivery to become a success, specifically in the works of Hudson, Hunter and Peckham (2019).

Despite the abundance of the literature and studies present, this study had not yet been 
explored by earlier research undertakings.

\subsection{METHODOLOGY}

\section{Research Design}

The researcher used the descriptive correlational research design in order to gather information relevant to the study. This helped in enhancing the relationships or associations between and among variables. It was affirmed by Creswell (2012), especially if the researcher seeks to establish the overall tendency of responses from individuals and to note how this tendency varies among people. It had combined a quantitative approach, in order to address the trends and ascertain the causes behind it, as well as the descriptive method, which is relevant to the descriptive statistic approach.

\section{Research Instrument}

The research instrument utilized in the study was adopted from the manual of Citizens Charter R.A. 9485.The survey questionnaire had an English version as well as Tagalog in order for respondents to understand them thoroughly. It was validated by experts before distribution, which were two (2) graduate school professors, one (1) institutional statisticial and one (1) representative from the Calamba Water District. Accordingly, it was divided into three parts: the respondent's profile, indicators of delivery standards of Citizen's Charter RA9485, and the level of stakeholders' satisfaction on the ease of doing business.

The second part wanted to determine the level of implementation by CWD in terms of procedure to obtain a particular service i.e. terms of procedure to obtain a particular service; the person/s responsible for each step, maximum time to conclude the process; document/s to be presented by the customer; amount of fees; and procedure for filing complaints, while the third part was in terms of customer service, quality of service delivery, easy transaction of documents and if all action and complaints are well taken.

The initial draft of the questionnaire was based on the related literature and studies gathered, and was further modified. It was consisted of 63 questions: 38 for the second part and 25 for the third part, and utilized the Four-Point Likert Scale. 


\section{Participants of the Study}

The respondents were composed of the Calamba Water District office personnel and customers or concessionaires who belong to non-governmental organizations. The G-score determined the 326 concessionaires as the number of respondents, while all $56 \mathrm{CWD}$ office personnel were asked to participate in the study.

\section{Data Gathering Procedure}

Non-probability purposive sampling technique is used, as the researcher had no ability to determine the particular population for the study. After determining the research instrument necessary for the study, the researcher sought permission from the CWD Management for the distribution of questionnaire. Upon successfully gaining permission, the researcher personally distributed the said questionnaire to the respondents and retrieval soon followed while abiding by minimum health safety protocols. The responses of the subjects was scored, tallied and tabulated for the purpose of data presentation, analysis and ultimate presentation. Afterwards, the researcher asked the assistance of a statistician to determine the appropriate statistical tools and proper treatment of the gathered data.

\section{Treatment of Qualitative Data}

To answer SOP 1 and 3, the weighted mean was used to determine the level of implementation of Citizen's Charter RA 9485 service delivery standards and the level of stakeholders' satisfaction on the ease of doing business. For SOP 2. the ttest for independent samples was employed to determine the significant difference on assessments of CWD personnel and customers on the implementation of Citizen's Charter (RA 9485).

Lastly, to establish the relationship between the extent of implementation of Citizen's Charter (RA 9485) and level of satisfaction on the ease of doing business in SOP 4, the Pearson product-moment correlation was employed. To give interpretation to computed Pearson correlation coefficient, the following guide was adopted:

\subsection{RESULTS AND DISCUSSION}

The extent of implementation of Citizen's Charter RA 9485 service delivery standards as assessed by the employees and concessionaires in terms of procedure to obtain a particular service indicates that Calamba Water District has fully implemented the 
Citizen's Charter RA 9485 service delivery standard in terms of procedure to obtain a particular service.

For the Level of Implementation of Citizen's Charter RA 9485 Service Delivery Standards of Calamba Water District (CWD) as Assessed by the Employees and Stakeholders in Terms of the Person/s Responsible for each Step, the study implied that Calamba Water District (CWD) fully implemented the Citizens Charter RA9485 service delivery standards in terms of the person/s responsible for each step. It only means that this government agency is compliant on the implementation or service standards of citizens charter R.A.9485 by providing or assigning enough personnel to take charge or be responsible to the needs of every customers or clients. It also implied that Calamba Water District (CWD) fully implemented the Citizens Charter RA9485 service delivery standards in terms of maximum time to conclude the process. It only signifies that CWD gave high consideration on the availability of the services during the office hours and proper information visible in the agency.

The results regarding the Stakeholders' Level of Satisfaction on the Ease of Doing Business at the Calamba Water District in Terms of Action and Complaint stated that the stakeholders of Calamba Water District (CWD) were fully satisfied on ease of doing business in terms of action and complaints. The stakeholders of Calamba Water District were fully satisfied on ease of doing business in terms of documentation requirements and processes and it was evident that the CWD employees are very prompt and responsive in handling inquiries and customer complaints, as shown in the the Stakeholders' Level of Satisfaction on the Ease of Doing Business at the Calamba Water District in Terms of Documentation.

For the test of significant relationship between the level of implementation of Citizen's Charter RA9485 service delivery standards and the level of stakeholders' satisfaction on the ease of doing business at the Calamba Water District, the findings of the study implied that the higher the implementation of the RA 9485 by the Calamba Water District, the higher the satisfaction of their stakeholders. Calamba Water District (CWD) fully implemented the Citizens Charter RA9485 service delivery standards in terms of document/s to be presented by the customer and amount of fees as well as procedures in filling complaints.

When it comes to the Test of Significant Difference on the Assessment of the Respondents on the Level of Implementation of Citizen's Charter RA 9485 Service Delivery Standards of Calamba Water District (CWD), there is significant difference on the assessment of the two groups of respondents on the extent of implementation of Citizen's Charter R.A. 9485 service delivery standards.

Furthermore, the study also proved that the ease of doing business at the Calamba Water District in terms of customer service are much appreciated by stakeholders. It only means that the CWD employees are great in citizen service especially in handling or giving priority to Senior Citizens and Person's with Disability and are fully satisfied with the CWD in terms of quality, delivery, documentation as well as action and complaint. 
When it comes to the regression analysis on the level of implementation of Citizen's Charter RA9485 service delivery standards to the level of stakeholders' satisfaction on the ease of doing business at the Calamba Water District in terms of quality and delivery. Based on the table, person responsible, process time, and fees significantly impact of the level of satisfaction on the ease of doing business at the Calamba Water District in terms of customer service. The three variables except on procedures on service, document requirements, and action and complaints significantly impact the quality and delivery by 77.4 \%., which means that Calamba Water District implementation of Citizen's Charter R.A. 9485 acquired an above average impact based on the stakeholders' satisfaction rating.

When it comes to the regression analysis on the level of implementation of Citizen's Charter RA9485 service delivery to the level of stakeholders' satisfaction on the ease of doing business at the Calamba Water District in terms of customer service, procedures on service, person responsible, Process time, documents, and amount of fees significantly impact of the level of satisfaction on the ease of doing business at the Calamba Water District in terms of customer service. The results revealed that the five variables except on action and complaints significantly impact the customer service by $78.8 \%$.

Based on the regression analysis on the level of implementation of Citizen's Charter RA9485 service delivery to the level of stakeholders' satisfaction on the ease of doing business at the Calamba Water District in terms of documentation, person responsible and Process time significantly impact of the level of satisfaction on the ease of doing business at the Calamba Water District in terms of customer service. The person responsible for every step of transactions and the process time significantly impact the customer service by 69.2\%, which only means that stakeholders of Calamba Water District would be fully satisfied if all aspects of the implementing rules and regulations of Citizen's Charter R.A. 9485 would be highly complied.

For the regression analysis on the Level of Implementation of Citizen's Charter RA9485 Service Delivery Standards to the Level of Stakeholders' Satisfaction on the Ease of Doing Business at the Calamba Water District in Terms of Action and Filling Complaints, the variables' procedures in service and documents required does not significant impact to the stakeholders' satisfaction on the ease in doing business with Calamba Water District. The probability values of $.000, .042, .022$ and .001 respectively are less than the level of significance at .05 , thus reject the null hypothesis. The results revealed that the three variables above significantly impact the action and complaints by $76 . \%$. 


\subsection{CONCLUSIONS/REFLECTIONS AND DIRECTIONS FOR FUTURE USE}

The study concluded, based on the information present, that the Citizen's Charter RA 9485 service delivery standards were fully implemented.

It was also evident that the Calamba Water District employees provide clear, highquality services to its customers in accordance with the implementation of ARTA at the Commercial Department of Calamba Water District. The researcher also discovered significant differences on how CWD personnel and stakeholders assess the implementation of Citizen's Charter, but had concluded that the overall perception of the ARTA implementation had shown that both types of respondents are aware of its existence.

Stakeholders are fully satisfied with the performance of CWD employees in addressing their concerns regarding their particular transactions. Aside from the abovementioned conclusions, the service delivery standards are significantly related to the satisfaction of the concessionaires. With this in mind, the researcher suggested that there is a need to enhance the delivery of service standards programs. This research aimed to pave the way for future researchers to improve the standards set for public services, as well as exploration on the effective implementation of the citizen charter

\section{ACKNOWLEDGMENT}

In grateful recognition and sincerest thanks for the effort, guidance, and unselfish sharing of knowledge, time, for the encouragement and untiring motivation that led to the completion of this work, the researcher acknowledges the following persons:

The panel of examiners, Diosdado O. Fernandez, PhD, chairman and the two other members, Ma. Lorena M. Tagala, EdD and Fernando T. Pendon III, PhD, FRIEdr, CSASS

for their valuable suggestions and recommendations for the improvement of this study; 
Prof. Maria Victoria C. Macale, her adviser, for her guidance, constructive criticism, and patience throughout the duration of preparing this precious work;

Dr. Eulalia M. Javier, her statistician, for her unselfish support and encouragement. It was great privilege to work under her supervision given her professional expertise and insightful comments had contributed in focusing my thoughts and ideas;

Dr. Fernando T. Pendon III and Prof. Marcelina DL. Perez, MBA, graduate school professors of LCBA and Dr. Maricris Unico, for sharing their proficiency in validating the questionnaires used in this study;

Management of Calamba Water District. especially to Mr. Exequiel A. Aguilar Jr., Ms. Pinky M. Elepaño, Mr. Nap N. Rodriguez Jr. and Mr. Ronnie G. Sierva, for the permission and untiring assistance and generous support;

Her colleagues, Tina, Junsy, Reyneth, Aleli, Malou T., Ethel, Princess, Kuya Henry and Ate Arlene J., Malou J., Amor, M'Sahlee, Boss Dei, Sir Robert, Depro, Karen, Investigation team and the late Tita Lau, Commercial Department and all her colleagues at Calamba Water District, for their moral support, guidance, and encouragement;

Her beloved parent, Mommy Jing, husband Ricky, and kids JB, Prince, and Drake, her apos, Ionna and Bryce, her sister, Sheila and family, for providing overwhelming patience, support, love and encouragement and inspiration that led to the completion of this challenging work; 
Above all, the Almighty God, for the enlightenment, guidance and blessings

He has showed upon the researcher that gave her courage, knowledge, and skills in order to finish this study; and

And to all of you who have made this work fruitful and possible!

\section{MCA}

\subsection{REFERENCES}

Antiporda, J. (2018). 5 govt agencies probed for corruption. [Article]. Retrieved November 2020 from https://www.manilatimes.net/5-govt-agencies-probed-forcorruption/400615/

Bocaue Water District Handbook (2021). Filing of Complaint. Copyright 2021. Accessed

from http://www.bocauewater.com/services/filing-of-complaint/

Brackertz, Nicola; Kenley, Russell (2014). A Service Delivery Approach to Measuring Facility Performance in Local Government. Emerald Publishing Vol. 20, Iss. 3/4: 127-135. Retrieved November 10, 2020 from http://www.emeraldinsight.com

Dudley, E., Yi Lin, D., Mancini, M. et. al. (2015). Implementing a citizen-centric approach to delivering government services. Retrieved November 21, 2020 from https://www.mckinsey.com/industries/public-and-social-sector/ourinsights/implementing-a-citizen-centric-approach-to-delivering-governmentservices\#

Framework of Citizen's Charter Handbook (2020). Indian Institute of Public Administration, New Delhi. Accessed November 15, 2020 from https://darpg.gov.in/sites/default/files/Framework_of_Citizens_Charter_IIPA.pdf

Gabriel, A.G. (2017). Praxis in Local Legislative Governance: Measure of Organizational Effectiveness of the Component Cities In Nueva Ecija, Philippines. Retrieved November 2020 from http://www.apjmr.co/wpcontent/uploads/2017/04/APJMR-2017.5.2.02.PDF 
Gabriel, A.G. (2017). Transparency and accountability in local government: levels of commitment of municipal councilors in Bongabon in the Philippines. Asia Pacific Journal of Public Administrtation, 39 (3), 217-223. Retrieved November 2020 from https://doi.org/10.1080/23276665.2017.1368902

Gabriel, A.G. (2018). Bureaucratic Red Tape in the Philippines In: Farazmand A. (eds.); Global Encyclopedia of Public Administration, Public Policy, and Governance. Retrieved November 2020.

Gabriel, A.G. and Ong, D.U. (2018). Linking Transparency and Accountability to Local Legislative Performance in the Provice of Nueva Ecija in the Philippines. Journal of Public Administration and Governance 384-396. Vol. 8, No. 2. Retrieved November 2020.

GAN Business Anti-corruption Portal. (2017). The Philippines Corruption Report. Retrieved November 2020 from https://www.business-anticorruption.com/country-profiles/the-philippines/

Heemsbergen, L.J. (2016). Transparency Measures in an International Context In: Farazmand A. (eds.); Global Encyclopedia of Public Administration, Public Policy, and Governance. Retrieved November 2020.

Holpp, Larry (2020). I Six Sigma. Accessed November 20, 2020 from https://www.isixsigma.com/methodology/business-process-management$\mathrm{bpm} /$ preparing-measure-process-work-time-study/

IRR R.A. 11032 Joint Memorandum Circular No. 2019-001 Series of 2019. Accessed from https://www.officialgazette.gov.ph/downloads/2019/ 07jul/20190717-RAIRR-11032-RRD.pdf.

ISO9001 (2015). ISO 9001 Requires That You Maintain Control of Documents. Accessed from the interne November 21, 2020 at https://the9000store.com/articles/iso9000-tips-document-control-requirements/

Medina-Guce, C., Saguin, Kidjie, and Jovellanos, K. (2020). Assessment of the AntiRed Tape Act Implementation for the Ease of Doing Business Act: Lessons from a Mixed Methods Approach. Retrieved November 20, 2020 from https://www.psa.gov.ph/sites/ 
Michals, D. (2013). Performance Measures in Government: Meeting Consumer Objectives in Human Service Delivery. The College of St. Scholastica, ProQuest Dissertations Publishing. Retrieved November 2020 from Proquest.com

Philippines 2017-2019 Action Plan (Updated). 8888 Citizens' Complaint Center (PH0047). Accessed November 20, 2020 from the internet at https://www.opengovpartnership.org/members/philippines/commitments/PH00 $47 /$

Rast, S. (2020). I Six Sigma. Accessed November 20, 2020 from https://www.isixsigma.com/implementation/change-managementimplementation/process-ownership-vital-role-six-sigma-success/

Rahaman, M.A. (2017). Governnace and Democracy In: Farazmand A. (eds.); Global Encyclopedia of Public Administration, Public Policy, and Governance. Retrieved November 2020.

Ricci, P. (2016). Transparency Measures in an International Context In: Farazmand A. (eds.); Global Encyclopedia of Public Administration, Public Policy, and Governance. Retrieved November 2020.

Selvanathan, M. (2019). Quality Service Delivery Systems among Government Agencies in Malaysia. Universiti Sains Malaysia. Retrieved November 29, 2020 from https://www.researchgate.net/publication/337484581_Quality_Service_Deliver y_Systems_among_Government_Agencies_in_Malaysia

Saunders, M., Lewis, P. \& Thornhill, A. (2012) "Research Methods for Business Students" $6^{\text {th }}$ edition, Pearson Education Limited p.288. Retrieved November 29, 2020 from https://research-methodology.net/sampling-in-primary-datacollection/purposive-sampling/\#_ftnref2

\section{APPENDIX}

\section{SURVEY QUESTIONNAIRE}

Dear Valued Respondents: 
The undersigned is conducting a study on the "SERVICE DELIVERY STANDARDS OF CITIZEN'S CHARTER R.A. 9485 OF CALAMBA WATER DISTRICT AND IT'S IMPACT TO THE EASE OF DOING BUSINESS WITH STAKEHOLDERS" as part of the requirements on her Graduate Studies at the Laguna College of Business and Arts.

In this regard, your cooperation in answering the questionnaire is highly appreciated. It is hoped that all questions included in the survey would be answered honestly and appropriately. Rest assured of the strict confidentiality of all data shared.

Thank you for giving your precious time to answer this survey questionnaire.

Very respectfully yours,

MONETTE CALPE ALZONA

Researcher

Part 1. Respondent's Profile

Name (Optional):

Age: Gender:

Type of Respondent $\square$ CWD Office Personnel

$\square \quad$ CWD Customer

Part II. This part aims to assess the level of implementation of Citizen's Charter R.A. service delivery standards of Calamba Water District.

I. Direction: Please answer the questions by checking the appropriate box that corresponds to your answer using the scale below.

Options Symbol

4 - Fully Implemented FI

3 - Implemented I

2 - Partially Implemented PI

1 - Not Implemented NI

A. The procedure to obtain a particular service CWD service delivery procedures observes...

1. Clarity of the services offered (kalinawan ng serbisyong 


\begin{tabular}{|l|l|l|l|}
\hline ibinibigay) & & & \\
\hline $\begin{array}{l}\text { 2. Accuracy of information given to customers (kawastuhan ng mga } \\
\text { impormasyong ibinibigay sa mga customer) }\end{array}$ & & & \\
\hline $\begin{array}{l}\text { 3. Accessibility to customers (madaling ma “access" ng mga } \\
\text { customer) }\end{array}$ & & & \\
\hline 4. Visible to the customers (madaling makita ng mga customer) & & & \\
\hline $\begin{array}{l}\text { 5. Efficiency of service provided ( Kahusayan ng serbisyong } \\
\text { binigay) }\end{array}$ & & & \\
\hline 6. Timeliness of the process ( maagap at nasa oras na proseso) & & & \\
\hline
\end{tabular}

\section{B. The person/s responsible for each step}

CWD frontliners observes...

1. Competence. (kakayanan)

2. Proper grooming and decorum (wastong pananamit at pag-uugali)

3. Punctuality in reporting to work (pumapasok ng tama sa oras)

4. Patience in dealing with others (mahinahon sa pakikipag-usap sa iba)

5. Commitment to public interest (nagpapakita ng"commitment" sa interés ng publiko)

6. Professionalism (nagpapakita ng "professionalism")

7. Nationalism and patriotism (nagpapakita ng pagiging nasyonalismo)

8.Commitment to democracy (nagpapakita ng "commitment" sa demokrasya)

9. Political neutrality (nagpapakita ng pagiging patas sa politika)

10. Simple living (nagpapakita ng simpleng pamumuhay)

11. Responsiveness to the public (medaling tumugon sa publiko)

12. Justness and Sincerity (nagpapakita ng pagiging patas at sinsero)

\section{The maximum time to conclude the process}

1. Adequate information displayed about the mandated time to complete a process or transaction is available. (sapat na impormasyong naka display tungkol sa itinalagang oras para matapos ang proceso o transaksyon)

2 Observance of the length of legally mandated time per transaction is followed. (pagsunod sa tagal ng oras ng transaksyon na legal na itinakda)

3. Availability of the services during the office hours is observed.

(pagkakaroon ng serbisyo sa oras na itinakda ng tanggapan ) 


\section{The document/s to be presented by the customer,}

1. Adequate information about the required documents is provided. (sapat na impormasyon tungkol sa kailangang mga dokumento ay ibinigay)

2. Completeness of the documents being required is observed. (kahustuhan ng mga hinihinging dokumento ay naobserbahan)

3. Legal basis of documents required is provided. (legal na basehan ng mga kailangang dokumento ay ibinigay )

4. Reasonableness of the documents being required is observed. (karampatan ng mga hinihinging dokumento ay naobserbahan)

5. Number of documents to be presented is provided ( bilang ng dokumentong hinihingi ay ibinigay)

6. Relevance of the documents being required ( kaugnayan ng mga dokumentong kinakailangan)

\section{E. The amount of fees, if necessary}

\begin{tabular}{|c|c|c|c|c|}
\hline The CWD provides. & FI & I & PI & NI \\
\hline $\begin{array}{l}\text { 1. Legal basis of fees being collected is followed. (legal na basehan } \\
\text { ng bayaring kinokolekta ay sinusunod) }\end{array}$ & & & & \\
\hline $\begin{array}{l}\text { 2. Adequate information about the fees to be collected is provided. } \\
\text { (sapat na impormasyon tungkol sa mga bayaring kinokolekta } \\
\text { ibinigay) }\end{array}$ & & & & \\
\hline $\begin{array}{l}\text { 3. Affordability of the terms or mode of payment is observed. (abot } \\
\text { kayang termino ng pagbabayad) }\end{array}$ & & & & \\
\hline $\begin{array}{l}\text { 4. Reasonableness of the amount base on the request is observed. ( } \\
\text { karampatang halaga batay sa kahilingan ay naobserbahan) }\end{array}$ & & & & \\
\hline $\begin{array}{l}\text { 5. Relevance of the amount of request is provided. ( kaugnayan ng } \\
\text { mga halaga ayon sa kahilingan ay naibigay) }\end{array}$ & & & & \\
\hline
\end{tabular}

\section{F. The procedure for filing complaints}

The CWD provides....

1. Clarity of the procedure is observed. (Kalinawan ng proseso ay naobserbahan)

2. Appropriateness of the procedure is followed. (kawastuhan ng proseso ay sinusunod)

3. Accuracy of the procedure is observed. (kahustuhan ng proseso ay naobserbahan)

4. Sequence of the procedure is followed. (tamang pagkakasunod ng proseso ay sinusunod)

5. Effectivity of time indicated for each process is observed. ( pagkamabisa ng itinakdang oras sa bawat proseso ay naobserbahan) 
6. Process flow to be taken in the procedure is provided. ( pamamaraan sa daloy ng itinakdang proseso ay naibigay)

PART III. The following statement will assess the level of stakeholders' satisfaction on the ease of doing business with Calamba Water District. Please answer the questions by checking the appropriate box that corresponds to your answer using the scale below.

$\begin{array}{ll}\text { Options } & \text { Symbol } \\ \text { 4- Fully Satisfied } & \text { FS } \\ \text { 3- Satisfied } & \text { S } \\ \text { 2 - Partially Satisfied } & \text { PS } \\ \text { 1 - Not Satisfied } & \text { NS }\end{array}$

\section{A. Customer Service}

\begin{tabular}{|c|c|c|c|c|}
\hline \multirow{2}{*}{$\begin{array}{l}\text { The Customer Service Division... } \\
\text { 1. Adheres to professional standards of conduct (sumusunod sa } \\
\text { pamantayan ng wastong pag uugali) }\end{array}$} & FS & $\mathbf{S}$ & PS & NS \\
\hline & & & & \\
\hline $\begin{array}{l}\text { 2. Has knowledge and confidence (may sapat na kaalaman at } \\
\text { kakayanan) }\end{array}$ & & & & \\
\hline $\begin{array}{l}\text { 3. Understands concessionaires needs (naiintindihan ang } \\
\text { pangangailangan ng mga kliyente ) }\end{array}$ & & & & \\
\hline $\begin{array}{l}\text { 4. Concessionaires can always contact someone for } \\
\text { inquiries/questions (may agarang nakakausap ) }\end{array}$ & & & & \\
\hline $\begin{array}{l}\text { 5. Relevance of information provided by frontliners (kaugnayan ng } \\
\text { mga inpormasyon ay naibigay) }\end{array}$ & & & & \\
\hline 6. Timelines of response ( Maagap at nasa oras na pag responde) & & & & \\
\hline $\begin{array}{l}\text { 7. Priority lane for Senior Citizen's and Person with Disability ( } \\
\text { May prioridad na linya para sa PWD at Senior Citizens) }\end{array}$ & & & & \\
\hline
\end{tabular}

\section{B. Quality and Delivery}

1. Conforms to specifications and requirements are observed. (pagsunod sa detalye at kinakailangan sa pagtugon ng serbisyo ay naobserbahan)

2. Manifests consistency and reliability of service delivered are manifested. (maasahan at patuloy na serbisyo ay naihayag)

3. Follows on-time delivery of service is observed. (agarang pag hatid ng serbisyo ay naobserbahan )

4 Availability of information is readily accessible and up to the minute. (agaran at pagkakaroon na ma -access ang mga detalye)

5. Compliance with the requirements is observed. ( pagtugon sa detalyeng kailangan ay naobserbahan)

6. Extension of service delivery with complicated request is being 
provided. ( pagbigay ng karagdagang serbisyo sa mga

komplikadong kahilingan ay naibigay)

\section{Documentation}

\begin{tabular}{|c|c|c|c|c|}
\hline \multirow{2}{*}{\multicolumn{5}{|c|}{$\begin{array}{l}\text { 1. Estimates/quotes are provided quickly and accurately (mga } \\
\text { presyo at serbisyo at mabilis at tama) }\end{array}$}} \\
\hline & & & & \\
\hline $\begin{array}{l}\text { 2. Timeliness in the submission of requested } \\
\text { documents/certifications is observed. (maagap sa pag sumite ng } \\
\text { hinihiling na dokumento ) }\end{array}$ & & & & \\
\hline $\begin{array}{l}\text { 3. Billing issues are fairly and satisfactorily resolved. (madaling } \\
\text { ma "access" ng mga customer ) }\end{array}$ & & & & \\
\hline $\begin{array}{l}\text { 4. Relevance of pertinent documents are observed. ( kaugnayan sa } \\
\text { may kinalaman na dokumento ay naobserbahan) }\end{array}$ & & & & \\
\hline $\begin{array}{l}\text { 5. Quality of documents being required is provided. ( kaledad ng } \\
\text { dokumentong hinling ay naibigay) }\end{array}$ & & & & \\
\hline $\begin{array}{l}\text { 6. Availability of printed materials indicating cost of every services } \\
\text { provided. ( pagkakaroon ng mga kopya babasahin sa mga } \\
\text { serbisyong ibinibigay) }\end{array}$ & & & & \\
\hline
\end{tabular}

\section{Action and Complaints}

\begin{tabular}{|c|c|c|c|c|}
\hline \multirow{2}{*}{$\begin{array}{l}\text { 1. Promptness in handling customer complaints (kadalian sa pag } \\
\text { hawak ng mga reklamo) }\end{array}$} & FS & $\mathbf{S}$ & PS & NS \\
\hline & & & & \\
\hline $\begin{array}{l}\text { 2. Complaint resolution. (solusyon sa mga reklamo maayos na } \\
\text { pinag-ugnay ) }\end{array}$ & & & & \\
\hline $\begin{array}{l}\text { 3. Responsiveness to enquiries is done promptly. (agad na } \\
\text { pagtugon sa mga katanungan) }\end{array}$ & & & & \\
\hline $\begin{array}{l}\text { 4. Service request response time is observed. (naobserbahan ng } \\
\text { aayon na oras matugununan ang kahilingan) }\end{array}$ & & & & \\
\hline $\begin{array}{l}\text { 5. Accuracy of solutions given is observed. ( kawastuhan ng mga } \\
\text { solusyon ay naobserbahan) }\end{array}$ & & & & \\
\hline $\begin{array}{l}\text { 6. Response time for every complaint in accordance with the } \\
\text { needed resolution is provided. ( naayong responde sa mga } \\
\text { kinakailangang solusyon sa mga reklamo) }\end{array}$ & & & & \\
\hline
\end{tabular}

THANK YOU SO MUCH 
